\title{
Overplanting in offshore wind power plants in different regulatory regimes
}

Wolter, Christoph; Klinge Jacobsen, Henrik; Zeni, Lorenzo; Rogdakis, Georgios; Cutululis, Nicolaos Antonio

Published in:

Wiley Interdisciplinary Reviews: Energy and Environment

Link to article, DOI:

10.1002/wene.371

Publication date:

2020

Document Version

Peer reviewed version

Link back to DTU Orbit

Citation (APA):

Wolter, C., Klinge Jacobsen, H., Zeni, L., Rogdakis, G., \& Cutululis, N. A. (2020). Overplanting in offshore wind power plants in different regulatory regimes. Wiley Interdisciplinary Reviews: Energy and Environment, 9(3). https://doi.org/10.1002/wene.371

\section{General rights}

Copyright and moral rights for the publications made accessible in the public portal are retained by the authors and/or other copyright owners and it is a condition of accessing publications that users recognise and abide by the legal requirements associated with these rights.

- Users may download and print one copy of any publication from the public portal for the purpose of private study or research.

- You may not further distribute the material or use it for any profit-making activity or commercial gain

- You may freely distribute the URL identifying the publication in the public portal

If you believe that this document breaches copyright please contact us providing details, and we will remove access to the work immediately and investigate your claim 


\title{
Overplanting in offshore wind power plants in different regulatory regimes
}

\author{
Christoph Wolter*, \\ Henrik Klinge Jacobsen*, Lorenzo Zeni†, Georgios Rogdakisł Nicolaos Cutululis ${ }^{\ddagger}$
}

Article Type:

Focus Article

\begin{abstract}
The development of offshore wind farms depends on many technical and economic parameters, which requires an integrated planning approach. Some parameters can be controlled by the wind farm developer, and some are determined by the regulatory authorities. Others can be outside control of both. One aspect of optimizing wind farm development is overplanting, which represents the capacity optimization between installed generation capacity and transmission capacity, which allows for a minor share of energy curtailment to increase the overall value of the farm. Quantifying this value also depends on the regulatory framework, which is analysed here by comparing UK and Danish conditions. Using a discounted cash flow model, we find that UK conditions are favourable to overplanting from the developer perspective, where the benefit of using the transmission cable more efficiently supports overplanting. In the Danish case the private-economic incentive to overplant is minor due to the constraint of linking subsidies to a certain energy output. On the other hand, when the cost of turbines declines relative to transmission system costs, overplanting tends to become more attractive. This is mostly the case when installing wind farms further offshore compared to projects closer to the coast, which has been exerted more and more exerted in the recent years. In a socioeconomic perspective, overplanting is also a viable method to optimize the wind farm technically and economically, if the cost of the additional turbines is less than the value of the additional generation that can be fed into the grid by the transmission line.
\end{abstract}

*DTU Management, Technical University of Denmark, Kongens Lyngby, Denmark

${ }^{\dagger}$ Electrical System Analysis, Ørsted Wind Energy, Gentofte, Denmark

${ }^{\ddagger}$ DTU Wind Energy, Technical University of Denmark, Ris $\varnothing$, Denmark 


\section{List of abbreviations}

$\begin{array}{ll}\text { A } & \text { Annual cost } \\ \text { CapEx } & \text { Capital Expenditure } \\ \text { CF } & \text { Cash flow } \\ \text { CfD } & \text { Contracts for Difference } \\ \text { DK } & \text { Denmark } \\ \text { E } & \text { Annual energy generation [MWh] } \\ \text { FLOW } & \text { Far and Large Offshore Wind } \\ I_{0} & \text { Upfront investment cost } \\ \text { i } & \text { Discount factor } \\ \text { IRR } & \text { Internal Rate of Return } \\ \text { LCoE } & \text { Levelized Cost of Electricity } \\ \text { N } & \text { Total hours } \\ \text { n } & \text { hour } \\ \text { NPV } & \text { Net Present Value } \\ \text { O\&M } & \text { Operation and Maintenance } \\ \text { OFTO } & \text { Offshore Transmission Operator } \\ P_{W} & \text { Wind power generation [MWh] } \\ p_{W} & \text { Technology-specific wind electricity market value [/MWh] } \\ \text { T } & \text { Operational lifetime } \\ \text { t } & \text { Year of operation } \\ \text { TSO } & \text { Transmission System Operator } \\ \text { UK } & \text { United Kingdom } \\ \text { WTG } & \text { Wind Turbine Generator }\end{array}$




\section{Introduction}

In the recent years, costs of offshore wind energy have come down and the development accelerated. In 2018 new offshore wind capacity of 2,649 MW were added in Europe, which still represents the global region with the largest deployment of offshore wind. The total installed capacity in Europe has been 18,499 MW by commissioning 409 new offshore wind turbines across 18 projects, raising the number of deployed and grid-connected turbines to 4,543 across 11 countries (Wind Europe, 2019). Development will continue to grow in Europe in the coming years but gradually offshore wind development in the rest of the world will take up a larger share. With the United Kingdom as the country with the largest development so far and Denmark representing a very early and different regulatory market, we compare these countries in this analysis of overplanting.

Capacity factors for offshore wind are higher than onshore and have in recent years increased further due to technology maturation as well as increasing installation share of offshore wind power plants further offshore with more favourable wind conditions. Yet the duration curves of offshore wind power plants are still far from full utilisation of the installed transmission capacity. In many cases of offshore wind farm planning, the transmission capacity has been dimensioned for the peak output of the wind farm, also because authorities or transmission system operators (TSO) often have been responsible to develop the transmission network, while the private developer constructs the wind farm itself. Furthermore, the support in some cases has been designed with a maximum supported power at any time corresponding to the generation fed into the national grid and thus the transmission capacity. Given this fixed transmission capacity, the objective of maximising the net present value (NPV) for the developer by varying the remaining design of the wind farm includes

examining the option of varying the generation capacity of the wind farm and implicitly the generation profile.

Overplanting aims to optimise the transmission system utilisation by increasing the wind power capacity above the transmission capacity limit. The installed capacity both can be expanded by installing an additional number of wind turbines, or by increasing the generator size of the turbines compared to the transmission system capacity and export cable. This 
article focuses on the former option of increasing the number of turbines during the planning stage, while other works in contrast have focused on the underinvestment in offshore wind transmission capacity (De Jonghe, van Hertem, \& Belmans, 2009). The different terms overplanting or capacity overinstallation in contrast to underinstallation or underinvestment generally describe the same manoeuvre to optimize the ratio between generation and transmission capacity by allowing for a small amount of energy curtailment. Nevertheless, overplanting or overinstallation better reflects the more straightforward method of modularly adding generation capacity during planning. Alterations in the transmission capacity on the other hand could otherwise also be confused with other primarily electrotechnical implementations like dynamic power rating, transmission voltage drop calculation and other measures not necessarily involving energy curtailment.

Fig. 1 visualises the effect of the overplanted capacity on the offshore wind power plant power curve. The extra installed capacity can be used to improve the power curve below rated wind speed and to make up for wind turbine unavailability, whereas the maximum deliverable power is capped so that energy has to be curtailed during high wind and turbine availability. Some level of curtailment has been seen as optimal in both onshore and offshore cases with constrained capacity in local grids or short-term system-wide excess generation as argued in (Klinge Jacobsen \& Schröder, 2012) and found by (National Grid, 2008). Since wind climates are usually characterized by an average wind speed lower than the rated power threshold of contemporary offshore wind turbines as exempified by Fig. 1, additional power can be generated during a considerable share of operation time, thereby utilising the transmission capacity more effectively and only curtailing a limited amount of generation. Further from shore, the generation time at rated wind power usually increases, whereas turbine availability is challenged by longer travel distances and repair times.

The optimisation of overplanting consequently opposes rising costs linked to the larger installation capacity and growing revenues from the boosted energy generation - since the grid connection setup is not altered, the transmission system cost remains constant.

A similar overplanting may also be relevant for other types of generation with a similar duration profile and constraints on connection to local grid or main grid. Chen et al. examine an onshore wind turbine case, that combines optimisation of curtailment with overplanting, 


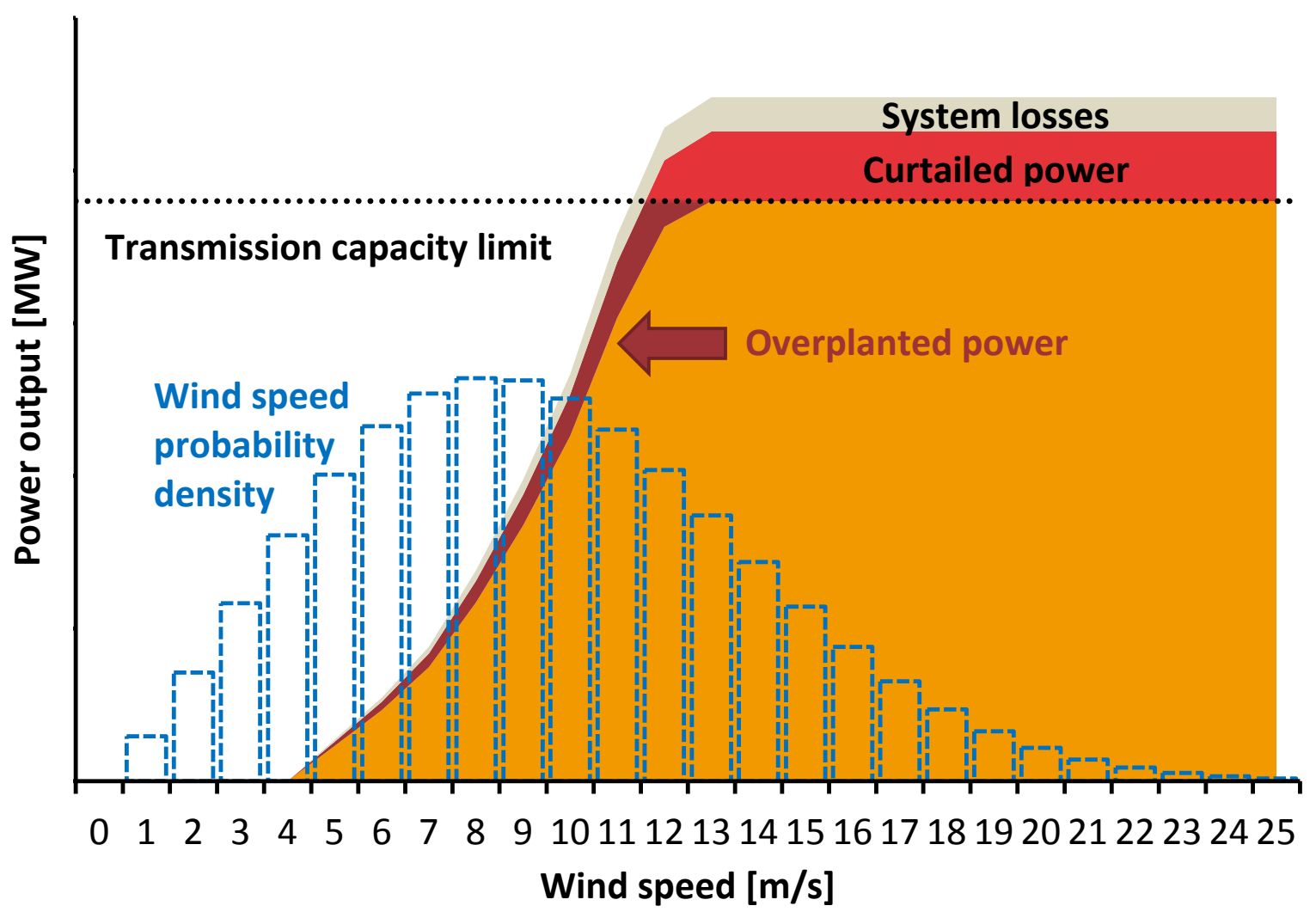

Figure 1: Illustration of the concept of overplanting 
which in that paper is referred to as capacity overinstallation (Chen \& Thiringer, 2017). They examine the correlation between local wind generation and market prices in Denmark and relate optimal curtailment to the value of curtailed generation that is influenced by the correlation with market price. Curtailed power has a lower value than average value of the generation from the turbine and this has a positive effect on the amount of optimal overinstallation.

Capacity optimisation so far has not been a prominent resource of reducing the levelised cost of energy (LCoE) of wind power plants. In fact, the optimal sizing between installed generation capacity and transmission capacity very much depends on the original cost of these two infrastructural components. A high cost share accounting for generation capacity gives lower incentives to overinstall the capacity. The historical development of offshore wind energy with the majority of early projects being placed close to shore resulting in low transmission system costs reflects the lack of consideration of overplanting in the early years of offshore wind development.

The optimisation of the capacity setup came into focus in 2008 with an assessment of optimal reinforcements of the British electricity transmission grid as part of the Round 3 leasing process (National Grid, 2008), suggesting an extra capacity of $12 \%$ as optimal average setup. In order to prevent regulatory restrictions in Grid Code requirements, Ireland raised their capacity cap by 15 percentage points to $20 \%$ above the maximum export capacity in order to exploit economic benefits from oversizing generation assets (Commission of Energy Regulation (CER), 2014). Likewise, the Dutch Ministry of Economic Affairs allowed an additional installation capacity of up to approximately $8 \%$ within the Borssele wind power plant tender in accordance with the development framework of a Dutch offshore grid (Netherlands Enterprise Agency, 2016). Recent studies have estimated the optimal additional installed capacity at 8-20\% above the transmission capacity for onshore wind energy in Ireland for varying renewable policy support systems (McInerney \& Bunn, 2017) as well as 2-5\% for offshore wind power plants in the framework of the United Kingdom (Baldock \& Henderson, 2014).

In the last years, the shorter term overplanting has consolidated indicating a greater awareness of this measure of capacity optimization in the offshore wind sector, both in 
research and as part of national planning procedures. Several works have focused on overplanting linking it to other considerations in wind farm planning like risk aversion (Borràs Mora, Spelling, \& van der Weijde, 2019), dynamic cable rating (Hernandez-Colin \& Pilgrim, 2019; Pérez-Rúa, Das, \& Cutululis, 2019), and being one optimization component of many integrated measures within national long term planning agendas (TKI Wind op Zee, 2019).

The considerable spread between optimal overplanting levels in the found literature shows the strong dependency between the considered wind farm technology, its geographic location and the regulatory framework it is embedded in. The present comparison of overplanting employed in different countries tries to reveal the main aspects relevant for an optimal capacity setup.

The prospects of overplanting will be evaluated economically by taking the perspective of private investors. In this way, we aim to highlight the effects of regulations set by policy makers on the investment decisions of private wind power plant developers. Relative to other studies (McInerney \& Bunn, 2017), regulatory impacts are compared across different countries and development areas. A discounted cash flow analysis model will be developed that estimates the investment cost of conceivable offshore wind power plants for different regulatory and geographic scenarios. Based on the economic analyses of different setups of additionally installed capacity, the optimal capacity setup will be characterised by the setup yielding the highest additional economic value.

In a market with a lot of wind generation the value of the wind that cannot be transported (curtailed generation) is probably rather low as the market price for most of these hours will be low. For a wind farm owner in most regulatory regimes the generation is remunerated according to the contract for differences price and curtailed power will lead to a partial postponement of this support. The loss from curtailed power and possible effects from timing of payout of support revenue is also considered as a consequence of the different regulation in place in the analysed cases.

The remainder of the paper will be structured as follows. Section 2 explains the methodology used for the national scenarios and the assumptions behind the wind power plant project investments. Section 3 successively presents the outcome of the economic analyses, followed by the sensitivity analysis in section 4. Finally, section 5 concludes the paper 
with a perspectivization of the findings with the literature and a discussion about policy implications. 


\section{Methodology}

\subsection{Evaluation parameters}

The economic assessment is carried out by two criteria. Firstly, the LCoE as common assessment measure for power generation technologies is used to evaluate the cost reduction potential per generated energy when optimising the capacity setup. LCoE is defined by Eq. 1.

$$
L C o E=\frac{I_{0}+\sum_{t=1}^{T} \frac{A_{t}}{(1+i)^{t}}}{\sum_{t=1}^{T} \frac{E_{t}}{(1+i)^{t}}}
$$

In this equation $I_{0}$ are the upfront investment costs, $A$ the annual costs in real terms in the year of operation $t$ up to a total operational time $T$ of a considered lifetime of 25 years, $i$ the discount factor with which the costs are discounted nominally considering inflation, and $E$ the annual energy generation discounted in real terms. The annual costs comprise O\&M cost, balancing costs on national power markets and payable tax from electricity generation revenues. Assumptions on the discount rates follow the suggestion of the national authorities, being 10\% in nominal terms in the United Kingdom (DECC (Department of Energy \& Climate Change), 2013) and 4\% in real terms in Denmark (Danish Energy Agency, 2016a). The difference between nominal and real terms constitutes a defined inflation rate of $2 \%$. The calculations do not specifically include financing costs and rather follow the standard approach of the authorities by excluding risk assessments from the present analysis.

The second measure is the internal rate of return (IRR) of the offshore wind power plant investment. The IRR derives from the NPV of the offshore wind power plant defined by Eq. 2, constituting the discount rate $i$ that sets the NPV to zero.

$$
N P V=-C F_{0}+\sum_{t=1}^{T} \frac{C F_{t}}{(1+i)^{t}}
$$

In this formula $C F$ represent all annual cash flows, i.e. costs and revenues. The IRR therefore fully considers revenues from energy generation and is more apt than LCoE to account for the different revenue streams of the national scenarios. Likewise, the IRR is independent from assumptions on the discount rate within the national scenarios, leading 
to a more general valuation of profitability throughout different scenarios independent of possible considerations regarding the discount rate as the investor's expected return or risk aversion.

\subsection{Offshore wind power plant scenario choice}

A hypothetical offshore wind power plant of $400 \mathrm{MW}$ baseline capacity corresponding to 50 wind turbine generators (WTG) of $8 \mathrm{MW}$ capacity is assumed throughout the economic analyses in order to account for comparability between the different scenarios. Instead of optimising the transmission voltage level to the wind power plant capacity, the different scenarios are modelled with a dedicated transmission voltage level of $220 \mathrm{kV}$. Although the realistic optimal voltage level can vary depending on the plant location by the length of the installed cable, this estimate seems sufficient for the present analysis. Three offshore wind power plant scenarios are analysed representing currently planned and consented projects in the United Kingdom and Denmark to reflect currently conceivable offshore wind projects. Values for water depth and distance to shore for various sites in those countries were gathered from an online database (4C Offshore, 2016) and their average values were assumed for the present national scenarios. Wind climates and numbers for average turbine availability were adapted from wind time series of comparable sites and the literature, respectively (Fichtner \& Prognos, 2013; Danish Energy Agency, 2016b). While Denmark is an offshore wind forerunner by installing the first offshore wind power plant, Vindeby, in 1991, the United Kingdom has become the leading market of offshore wind energy with $46 \%$ of the European installed capacity situated in British waters by the end of 2015 (EWEA, 2016). This share has remained roughly constant up to the end of 2018 (Wind Europe, 2018). The United Kingdom is therefore reflected by two different scenarios, the Conventional British offshore wind power plant reflecting average characteristics of projects closer than $100 \mathrm{~km}$ far from shore, and the Far offshore British wind power plant reflecting exceeding distances. The Danish scenario is named Average Danish offshore wind power plant. Table 1 exposes the geographic characteristics of the three hypothetical offshore wind power plants. The higher mean wind speed and slightly lower turbine availability for the Far offshore British wind power plant tries to account for the higher wind climate for and longer travel times to sites 
Table 1: Locational characteristics of the scenarios.

\begin{tabular}{lcccc}
\hline $\begin{array}{l}\text { Offshore wind } \\
\text { power plant }\end{array}$ & $\begin{array}{c}\text { Water } \\
\text { depth }\end{array}$ & $\begin{array}{c}\text { Distance } \\
\text { to shore }\end{array}$ & $\begin{array}{c}\text { Mean } \\
\text { wind speed }\end{array}$ & $\begin{array}{c}\text { Turbine } \\
\text { availability }\end{array}$ \\
\hline $\begin{array}{l}\text { British conventional } \\
36 \mathrm{~m}\end{array}$ & $29 \mathrm{~km}$ & $9.5 \mathrm{~m} / \mathrm{s}$ & $95 \%$ \\
British far offshore & $29 \mathrm{~m}$ & $151 \mathrm{~km}$ & $10 \mathrm{~m} / \mathrm{s}$ & $94 \%$ \\
Danish average & $19 \mathrm{~m}$ & $18 \mathrm{~km}$ & $9.5 \mathrm{~m} / \mathrm{s}$ & $95 \%$ \\
\hline
\end{tabular}

further offshore.

\subsection{Investment cost assumptions}

In order to analyse the economic profitability of the hypothetical offshore wind power plant scenarios, all relevant costs were estimated depending on specific cost drivers in order to allow for changes of geographic locations within the national scenarios. To further account for changes in the scope of investment according to national regulations, the costs are expressed by the following cost components, distinguished between costs for the wind power plant itself and the transmission system cost:

Wind power plant cost components:

- Development expenditure

- Turbines \& array cables

- Foundations

- Installation of offshore wind power plant components

Transmission system cost components:

- Offshore substation

- Export cable supply cost 
- Installation of export cable

- Onshore substation

The separation of cost components reflects the diverse legislation concerning the cost allocation of the total offshore wind power plant investment. Currently, the common practice of offshore wind power plant developers in the United Kingdom is to construct and bear the cost of all project components. The developer then has to handle the grid connection agreement of the offshore wind power plants separately with the TSO in the following way: Developers are required to sell the transmission infrastructure to an offshore transmission owner (OFTO) by a competitive tender, who then owns and operates the asset for a dedicated contract length of 20 years (KPMG, 2014). The OFTO can in turn charge transmission fees to the developer to use the infrastructure, in order for the OFTO to recover his investment (GWEC, 2014). The transmission fees are therefore dependent on the original investment and the developer thus has a direct incentive to find the optimal combined solution, which overplanting can be a part of.

The Danish regulation in contrast has required the TSO to be the responsible entity in terms of construction and investment of the transmission system infrastructure. In this case, the wind farm developer is thus given less room for system optimization, as its responsibility ends at the offshore substation being part of the TSO's transmission system (GWEC, 2014). This approach is similar to the regulations among others in the Netherlands and to some extent Germany. Although the Danish regulations were updated in 2019 affecting the transmission system in that the wind farm developer itself will bear the investment costs of the transmission system as well, similar to the British regulations, the offshore wind power plant Kriegers Flak currently under construction still falls under the previous regulation as explored in this paper.

The reduction of the project scope in the Danish case is expected to show a negative effect on the profitability to overplant the offshore wind power plant with respect to the British case. Since the relative cost increase per added turbine is higher in a case where the transmission system is not part of the developer's investment, the economic benefits of the 
additionally generated energy are consequently lower.

Project planning cost inclusively other costs as insurance or contingencies, or development expenditure, characterise fixed planning costs of the investment independent of specific cost drivers. They are assumed to amount to $300 € / \mathrm{kW}$, which is in the range of several other offshore wind power plant cost analyses (Fichtner \& Prognos, 2013; PwC, 2012). Assumptions for the residual investment cost follow mainly the information given in the analysis of another paper by Voormolen et al. (Voormolen, Junginger, \& van Sark, 2015), which gives an extract of the confidential data set used within the FLOW (Far and Large Offshore Wind) project by the Dutch Top Consortium for Knowledge and Innovation Offshore Wind (TKI Wind op Zee, 2016). These assumptions were adapted and refined to make them applicable to the characteristics of the considered offshore wind power plant.

Table 2 lists the cost components that are considered to be solely dependent on the installed capacity of the offshore wind power plant. In reality the turbine supply cost is dependent on further cost drivers like the development of the supply chain, raw material prices and broader macroeconomic conditions, which has been mentioned and partially tried to account for in other articles regarding offshore wind investment cost development (Voormolen et al., 2015; Van der Zwaan, Rivera-Tinoco, Lensink, \& van den Oosterkamp, 2012). For the present analysis, the presented trend of specific turbine costs within (Voormolen et al., 2015) makes it sufficient to define the cost at $1,800 € / \mathrm{kW}$ as a reference for the different investigated scenarios. It is assumed that this price level contains the costs for array cables, which are not defined separately, as they usually represent a minor part of investment cost of offshore wind power plants (IRENA, 2012).

The estimated cost for an offshore substation within this paper is also used in other scientific literature (Prässler \& Schaechtele, 2012). The cost for an onshore substation, which is not part of the publicly available FLOW model data, was derived to be $25 \%$ of the cost for an offshore substation. This lower value with regard to the offshore substation cost is reflected by the dominance of the offshore substation foundation cost over other components within substations such as transformer or switchgear cost and reflects the analyses of other literature (Dicorato, Forte, Pisani, \& Trovato, 2011; DTI (Department of Trade and Industry), 2007). The present work assumes that only foundation cost is related to the water depth. Since 
the foundation cost is linked to the deployed turbine and its size, the foundation cost curves depending on water depth from the FLOW model were adapted to the present wind power plant setup. Power regression curves of the foundation costs over different sizes of WTG for specific given water depths defined the equivalent foundation cost values of the $8 \mathrm{MW}$ WTG for these depths. Fig. 2 shows these data values with the best fit function, with which foundation cost is expressed for other water depths. The data set contains foundation costs for monopiles, comprising $80 \%$ of all substructures of the European operating wind power plants, and jacket foundations, which is the leading type of foundations for deeper waters (EWEA, 2016). No further differentiation between other installable foundation types is therefore considered necessary for the present analysis. The most cost-effective foundation type for different water depths is then taken for the hypothetical offshore wind power plant.

Table 3 lists the cost components related to the distance to shore, to which the export cable is directly linked. The export cable supply and installation cost deviates from the FLOW model, since the dedicated transmission capacity of $220 \mathrm{kV}$ is not among the public data. Export cable supply costs of $1,500 € / \mathrm{m}$ are presented in (Van Eeckhout, Van Hertem, Reza, Srivastava, \& Belmans, 2009), while the proportion between cable supply and installation cost for a comprehensive dataset of $220 \mathrm{kV}$ cables, however for smaller power capacities than in the present setup, is presented to be in the ratio $2: 1$.

Although a project resembling the British far offshore wind power plant would imply the construction of an HVDC transmission system with slightly different financial characteristics, it was chosen not to distinguish the transmission setup further. Alternatively, the correlation between export cable length and distance to shore was studied in more detail. The distances of export cable length of the same sets of projects defining the different wind power plant scenarios were compared with the distance to shore and expressed by a multiplication factor, the distance to shore itself being characterised by the factor 1. Average ratios of cable length to distance to shore of $18 \mathrm{UK}$ projects leading to the Conventional British offshore wind power plant are at 1.56, while the average ratio of the two consented Danish offshore projects considered are close to that value with 1.65 (4C Offshore, 2016). Many projects within the British far offshore category lack a specific cable length due to their early planning stage. The present approach assumes a ratio of 1 for this scenario in order to minimise the 


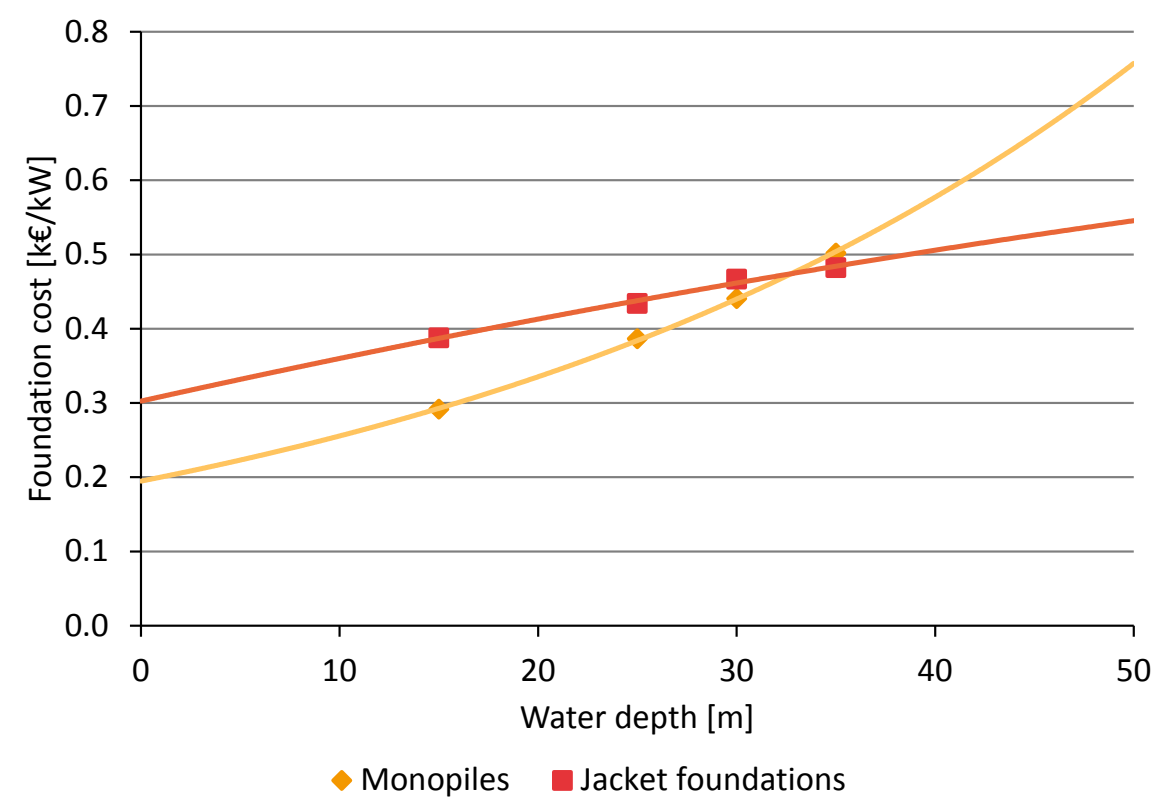

Figure 2: Monopile and jacket foundation costs for an 8 MW WTG

cable supply costs for these setups, a likely action to prioritise minimal costs for cable routing of far offshore wind power plants, and also qualitatively to account for the economic advantage of HVDC connections with respect to HVAC systems for far offshore cases. For a more detailed comparison of HVAC and HVDC systems, see also (Van Eeckhout et al., 2009).

\subsection{Annual cost assumptions}

The main component of the annual costs is O\&M cost. In general, information regarding O\&M cost is hard to obtain. The literature estimates O\&M cost to be in a wide range of 15-49 $€ / M W h$ (Kitzing \& Morthorst, 2015). Other scientific sources express the costs as 2.5$4 \%$ p.a. in fixed terms as share of CapEx (Heptonstall, Gross, Greenacre, \& Cockerill, 2012; Prässler \& Schaechtele, 2012). As the O\&M cost strongly depends on the distance to shore (by means of the distance to the nearest maintenance port) (Kitzing \& Morthorst, 2015), the expression in fixed terms can be considered to be suitable to account for this effect. Since investment costs of offshore wind power plants tend to rise with an increasing distance to shore, a fixed percentage of these costs expressing the O\&M cost will rise accordingly. Due to 
Table 2: Specific costs related to the installed capacity

\begin{tabular}{ll}
\hline Component & Specific cost \\
\hline Turbine \& array cable cost & $1,800 € / \mathrm{kW}_{\text {installed }}$ \\
Offshore substation & $210 € / \mathrm{kW}_{\text {transmission }}$ \\
Onshore substation & $52.5 € / \mathrm{kW}_{\text {transmission }}$ \\
\hline
\end{tabular}

the uncertainty of quantifying the O\&M cost, a relative share of the detected lower boundary of $2.5 \%$ p.a. of CapEx was considered, which is also in the range of numbers suggested by the British and Danish ministries and authorities for energy (DECC (Department of Energy \& Climate Change), 2013; Danish Energy Agency, 2016b). This percentage was thus adapted throughout all scenarios.

In both countries, the offshore wind power plant operator is obliged to pay for occurring balancing costs on the power market. The respective height of balancing costs depends on many factors, among which are the respective production portfolio, balancing market design, or the interconnection with the surrounding national electricity systems. Balancing costs were found to be slightly higher in the United Kingdom compared to Denmark. For the analysis, $3 € / \mathrm{MWh}$ in the UK and $2 € / \mathrm{MWh}$ in Denmark are applied, following respective literature (EWEA, 2015; Danish Energy Agency, 2015).

The last component of the annual costs characterises tax payments of revenues gained from the electricity sales. Respective corporate tax rates are applied to account for these additional costs per energy generation.

\subsection{Revenue assumptions}

Table 4 shows the main aspects of the latest national support regulations of governmental tenders of the United Kingdom and Denmark. Both countries have moved to the application of sliding feed-in premiums in order to expose the renewable generators to the electricity market.

The support price of tenders in both nations is determined for single projects, for which the total remuneration or strike price is bid by prospective investors. The payments for the 
Table 3: Specific costs related to the distance to shore

\begin{tabular}{ll}
\hline Component & Specific cost \\
\hline Export cable $220 \mathrm{kV}$ & $1,500 € / \mathrm{m}_{\text {cable length }}$ \\
Installation of export cable & $750 € / \mathrm{m}_{\text {cable length }}$ \\
Installation of turbines and foundations & $4,000 € / \mathrm{km} / \mathrm{MW}_{\text {installed }}$ \\
\hline
\end{tabular}

Table 4: Overview of support schemes

\begin{tabular}{lcc}
\hline Country & United Kingdom & Denmark \\
\hline Support scheme & Feed-in premium \\
\hline Remuneration & Project-specific (tender) \\
\hline Market price determination & Hourly average price \\
\hline Granted period & 15 years & 50,000 full-load hours or \\
& & max. 20 years \\
\hline
\end{tabular}

consented project to the winning bidder then consist of the hourly electricity price on the respective power market and the sliding difference to the bid price as support payments. While the support payments are granted over 15 years for these projects in the United Kingdom, the total support level in Denmark corresponds to a fixed level of energy generated, often expressed by a specific amount of full-load hours being supported, if not stopped after 20 years of remuneration. 50,000 full-load hours are equivalent to approximately 11-13 years of support payments for capacity factors of contemporary Danish offshore wind power plants.

Overplanting offshore wind power plants with the effect of a rise in capacity factors will have an influence on the support payment period of Danish projects. While the support payments are completely remunerated at an earlier point in time, which has benefits on the discounting of revenues, the overplanted power plant seen as a whole investment subject will also face a longer residual operational time in which it only receives lower power market prices for electricity sales. British projects in contrast will receive the same support and market payments per MWh over the lifetime independent of additional capacity installations.

Table 5 presents the assumptions for strike price and average power market price that 
are assumed for the feasibility analyses. The price levels are derived from empirical datasets of previously tendered offshore wind projects in both countries, and the recent development of power market prices in the day-ahead markets of the United Kingdom and Denmark. Previous bid support levels of offshore wind power plants in both countries were weighted by the installed capacity of the projects as well as inflated and adjusted for currency exchange. The outcome of the two first governmental tendered offshore projects in the United Kingdom (DECC (Department of Energy \& Climate Change), 2016a) and Denmark (Danish Energy Agency, 2017) can be found in the literature. Due to the considerable production of wind power in the Danish power system that totalled a share of $43.6 \%$ on the gross consumption level in 2017 (Energinet.dk, 2016), the market prices were adjusted towards an expectable price level for wind power producers. The literature shows that a higher penetration rate of variable renewable energy (VRE) sources has a negative effect on the price that these VRE receive on the electricity market (market value) (Hirth, 2013). Wind power generators in Denmark should therefore expect lower revenues for their provided energy than the average remuneration on the electricity market. The market value of a generator can be calculated by Eq. 3.

$$
\bar{p}_{W}=\frac{\sum_{n=1}^{N} P_{W, n} \cdot p_{n}}{\sum_{n=1}^{N} P_{W, n}}
$$

In this equation $\bar{p}_{W}$ is the average market value or electricity price of wind power generators, $P_{W}$ the wind power generation in hour $n$ of in total $N$ hours, and $p$ the hourly market price. In fact, the market value of wind power generators being expressed in Table 5 was determined to be $11.2 \%$ lower than the average electricity market price of the investigated time frame. The average market value of offshore wind power plants in the United Kingdom was not considered, as the historic market value of wind has been found close to the average electricity price (DECC (Department of Energy \& Climate Change), 2016b). This could either be due to the lower share of wind power in the British electricity system compared to Denmark, or due to a larger geographic spread of British wind farms leading to fewer hours of aggregated low-cost wind power in the market, as more and more observed in the geographically smaller Danish electricity market zones.

The numbers suggest that the conditions in the United Kingdom are more potent to yield 
Table 5: Revenue assumptions in scenarios

\begin{tabular}{lcc}
\hline Country & United Kingdom & Denmark \\
\hline Strike price & $162 € / \mathrm{MWh}$ & $114 € / \mathrm{MWh}$ \\
Power market price $^{1}$ & $55.9 € / \mathrm{MWh}$ & $27.8 € / \mathrm{MWh}$ \\
\hline
\end{tabular}

${ }^{1}$ UK: ofgem data, 2014-2018; DK: NordPool Elspot, 2014-2018, adjusted for wind market value

higher returns on the investment for developers if they face comparable levels of specific investment costs in both countries, as the present work assumes. Expectable power market remunerations are approximately twice as high on the British spot market compared to the Danish NordPool price area. 


\section{Cost-benefit analysis}

The results of the present work show the cost estimations for the hypothetical offshore wind power plants, as well as the optimal overplanting level concerning cost reduction potential and economic value gain. While the quantitative addition in economic value of the power plant is reliant on the underlying assumptions of revenues, the optimal capacity addition can be considered unbiased from these considerations, since the relative trend of LCoE and IRR over different levels of overplanted capacity is mainly unaffected from the height of the revenues.

\subsection{Comparison of investment cost}

Fig. 3 shows the investment cost estimations of the three scenarios. The two projects closer to shore need comparable total investment costs of around 3,000 $€ / \mathrm{MW}$. The cost for the power plant developer of the Danish project however is around 15\% lower than the total project cost, since the cost for the transmission system is borne by the TSO. The investment cost for the British project located far offshore is significantly higher and surging over 4,200 $€ / M W$, mainly due to the rising cost for the transmission system constituting roughly $26 \%$ of the total project cost. Since the far offshore sites in the United Kingdom constituting the present scenario are characterised by in average lower water depths than sites closer to shore, the distance to shore is the main cost driver in the direct comparison of the British scenarios.

\subsection{Overplanting in different regulatory regimes}

Fig. 4 visualises the impact of overplanting on the Conventional British offshore wind power plant. It shows the relative increase in AEP and necessary curtailment over the different setups of additional capacity, along with the relative change of $\mathrm{LCoE}$ and IRR with respect to the baseline capacity. In the present setup, an additional capacity of $4 \%$ above the baseline capacity characterises the optimal setup considering both LCoE reduction potential and gain in IRR. The corresponding addition of economic value in the optimal design is at +29.5 mio $€$ with an LCoE of $105.91 € / M W h$.

Fig. 5 shows the optimal level of overplanting for the Far offshore British wind power 


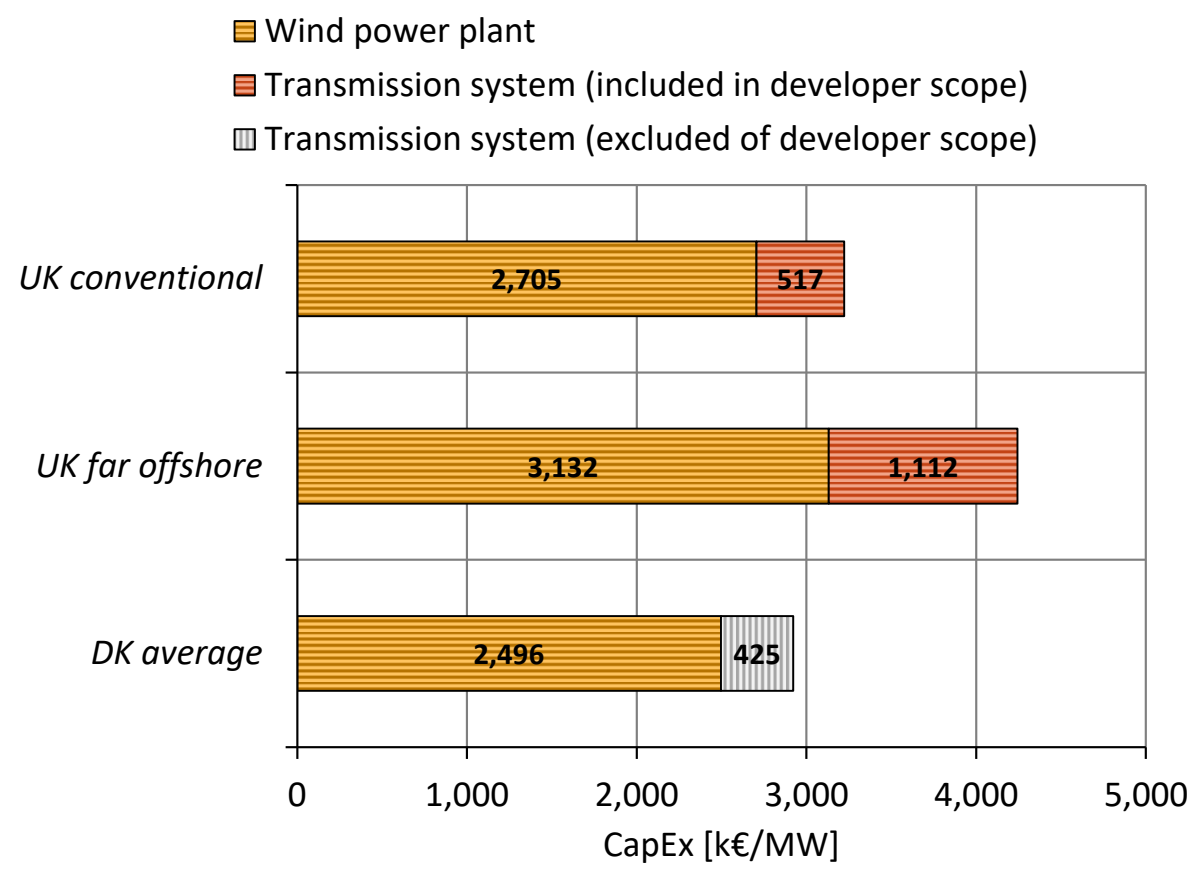

Figure 3: Investment costs of the scenarios. The Danish transmission costs shaded in grey indicate that the developer is not financially responsible for the transmission system.

plant. Most notably the more prominent transmission system cost as part of the total project cost further favours overplanting towards an optimal level of $6 \%$. The LCoE reflects the higher investment costs of projects with an extended distance to shore, being greater than the previous scenario with $124.44 € / \mathrm{MWh}$ in the optimal design. The scenario reveals a higher LCoE reduction potential as well as slightly more economic benefits due to an increased capacity addition: With the same underlying revenue assumptions, also the gain in economic value is still comparable, being at +34.0 mio $€$ for the optimal design.

Fig. 6 shows the outcome for the Average Danish offshore wind power plant. The two evaluation parameters diverge and reveal the negative effect of the support scheme regulations on the viability of overplanting. An LCoE reduction potential is still apparent even without the transmission system in consideration, since static costs for project planning as well as an increase in the capacity factor continue to promote overplanting. An increase in AEP of $3.7 \%$ can be achieved in the optimal design, lifting the energy generation by 1.8 percentage points to a capacity factor of $49.5 \%$ with respect to the fixed transmission capacity. 


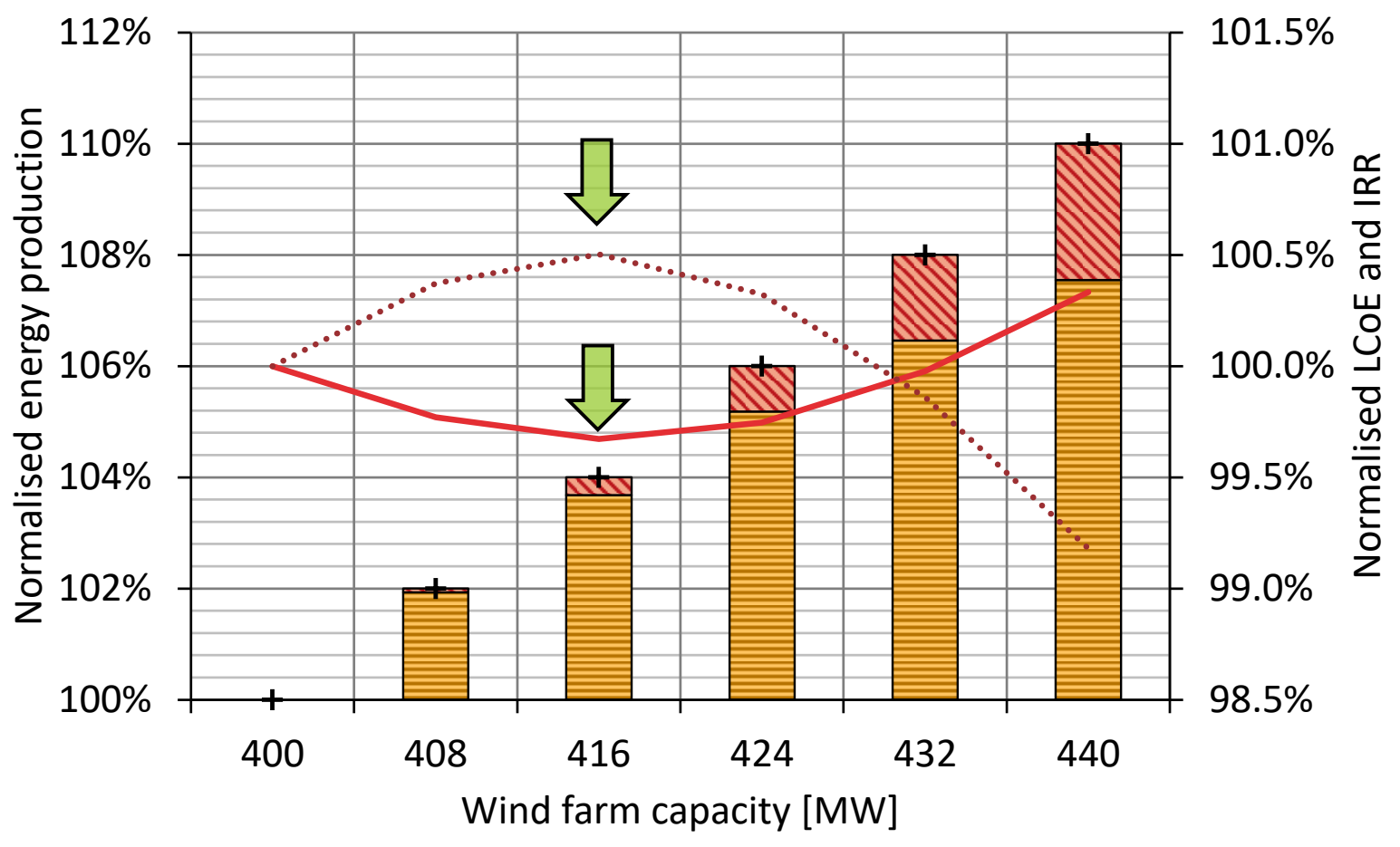

$\square$ Normalised energy production $\quad$ Normalised curtailed energy — Normalised LCoE .... Normalised IRR

Figure 4: Business case impact for the Conventional British offshore wind power plant 


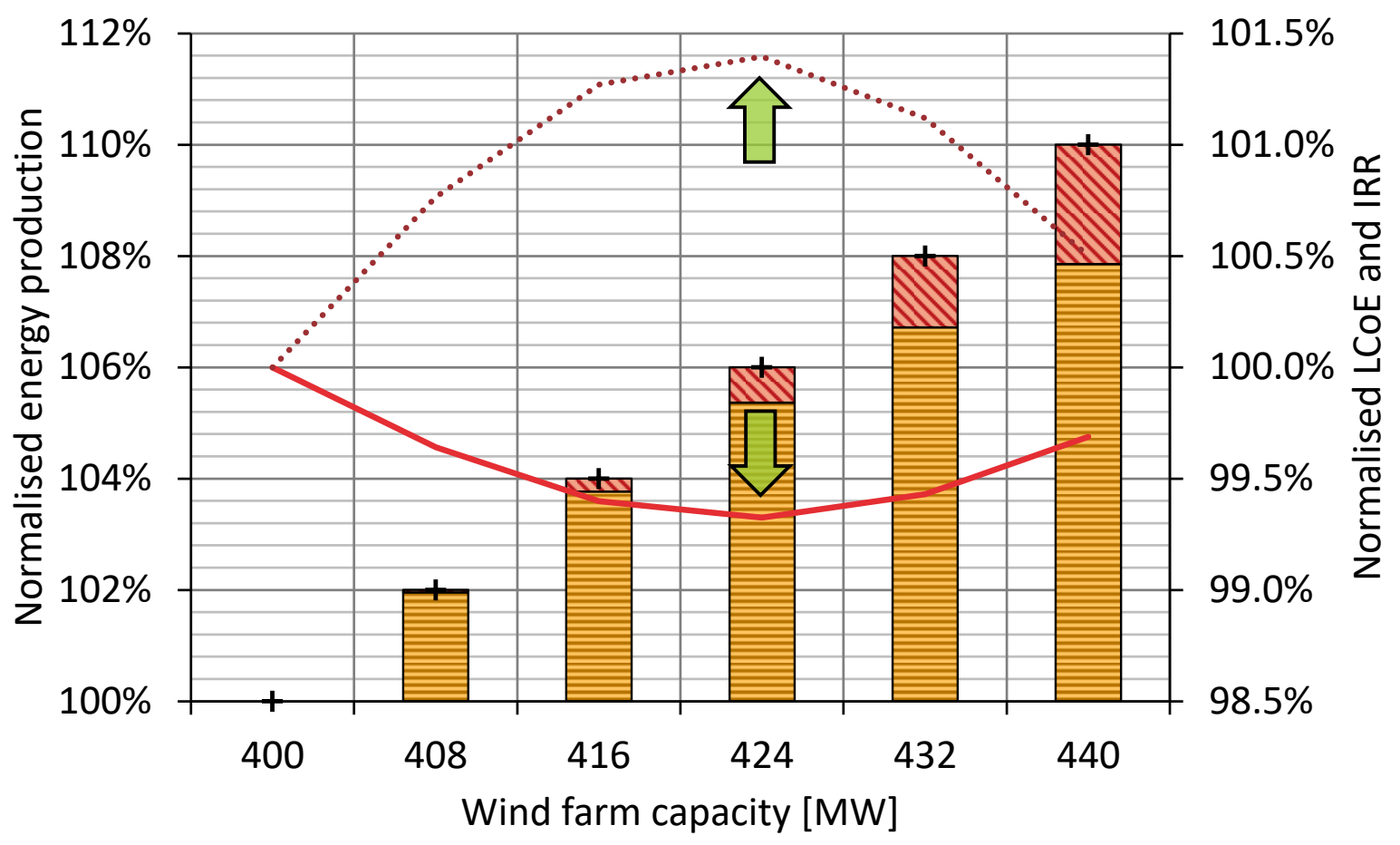

$\Xi$ Normalised energy production $\quad$ Normalised curtailed energy

—Normalised LCOE _... Normalised IRR

Figure 5: Business case impact for the Far offshore British wind power plant 


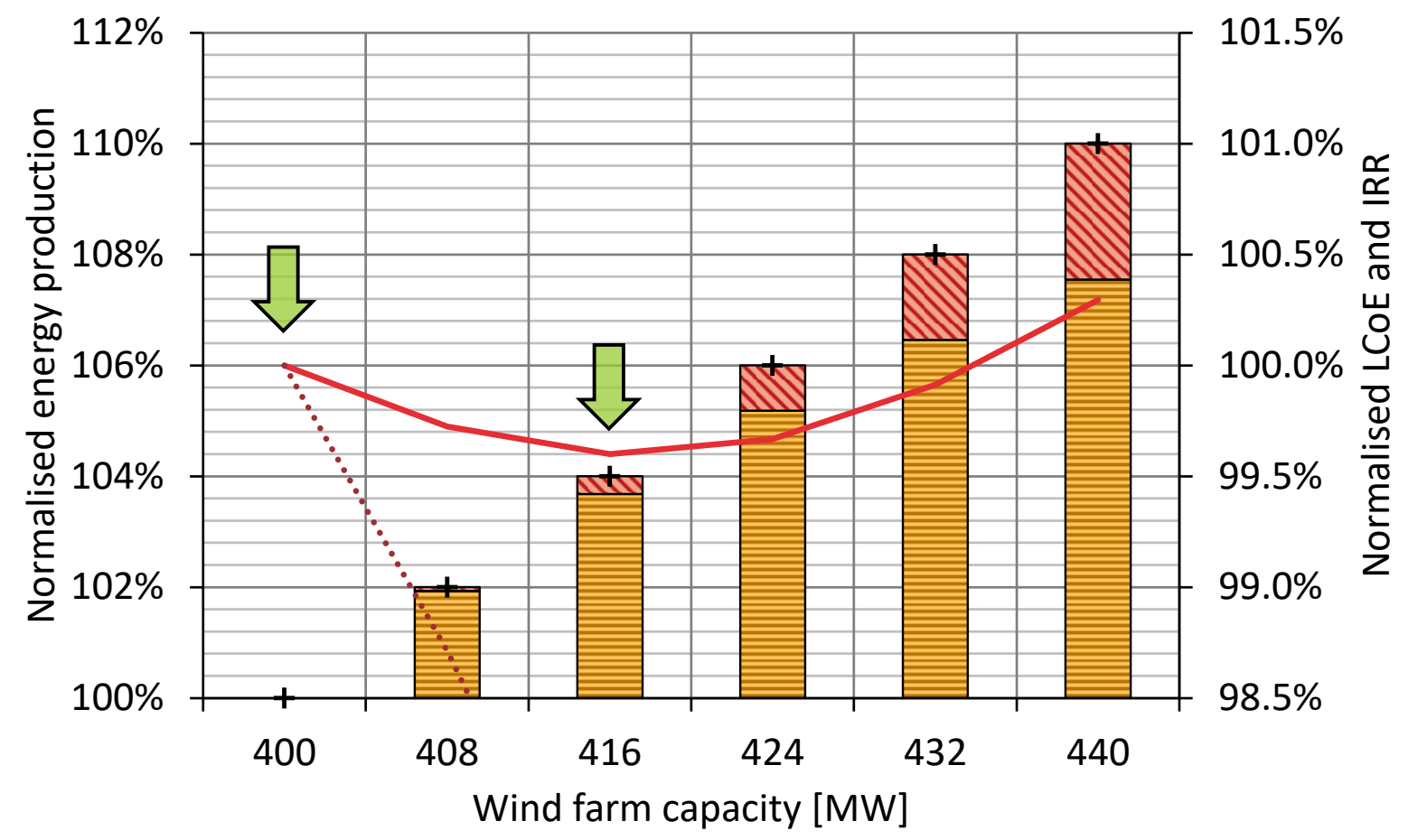

$\square$ Normalised energy production — Normalised LCoE
$\mathbb{N}$ Normalised curtailed energy .... Normalised IRR

Figure 6: Business case impact for the Average Danish offshore wind power plant

Yet the remuneration of the wind power plant based on a fixed level of energy generation causes the additional generated energy per overplanted wind turbine to be less valuable for the developer. The slightly earlier remuneration does not make up for more earnings only gained on the power market with respect to the total capacity installed, which reimburses the generated energy for lower prices. 


\section{Sensitivity analysis}

The sensitivity analysis presents the influence of the wind climate and turbine availability on the prospects of overplanting by using the Conventional British offshore wind power plant scenario as example. Financial sensitivities have shown only little effect on the relative change of the evaluation parameters, since the different capacity setups of the wind power plants are equally affected by varying support revenues and power market prices. Even for the Danish regulations, in which the relation between support level and market price can play a role on the optimal rate of return, the implications of the analysis remains unchanged when considering reasonable alterations in these variables.

\subsection{Wind climate}

Fig. 7 shows the effect of a change in the wind climate on the optimal design of the offshore wind power plant. With a lower mean wind speed the time generating at rated power also decreases, reducing the amount of necessary curtailment and favouring the installation of additional capacity. A higher mean wind speed in contrast counteracts overplanting due to a longer generation time at rated power. Although the LCoE ranges from approximately 101-112 $€ / M W h$ in the analysis, the wind climate shows little affect on the LCoE reduction potential for the low additions of capacity in which an optimal overplanting level is found for contemporary offshore wind power plants. The optimal design remains unaffected at $4 \%$ above the baseline capacity for all cases.

\subsection{Turbine availability}

Fig. 8 shows a reasonable change in average turbine availability and the effect on optimal overplanting. A decreased average turbine availability reduces the time that the wind power plant utilises the full capacity of the transmission system and favours overplanted installation capacity and its ability to compensate for lost power. High average turbine availabilities contrarily reduce the need for this compensation. The analysis shows that a change in availability highly influences the optimal design level, even though the LCoE over all cases stay at a close level with 105-107 $€ /$ MWh. 


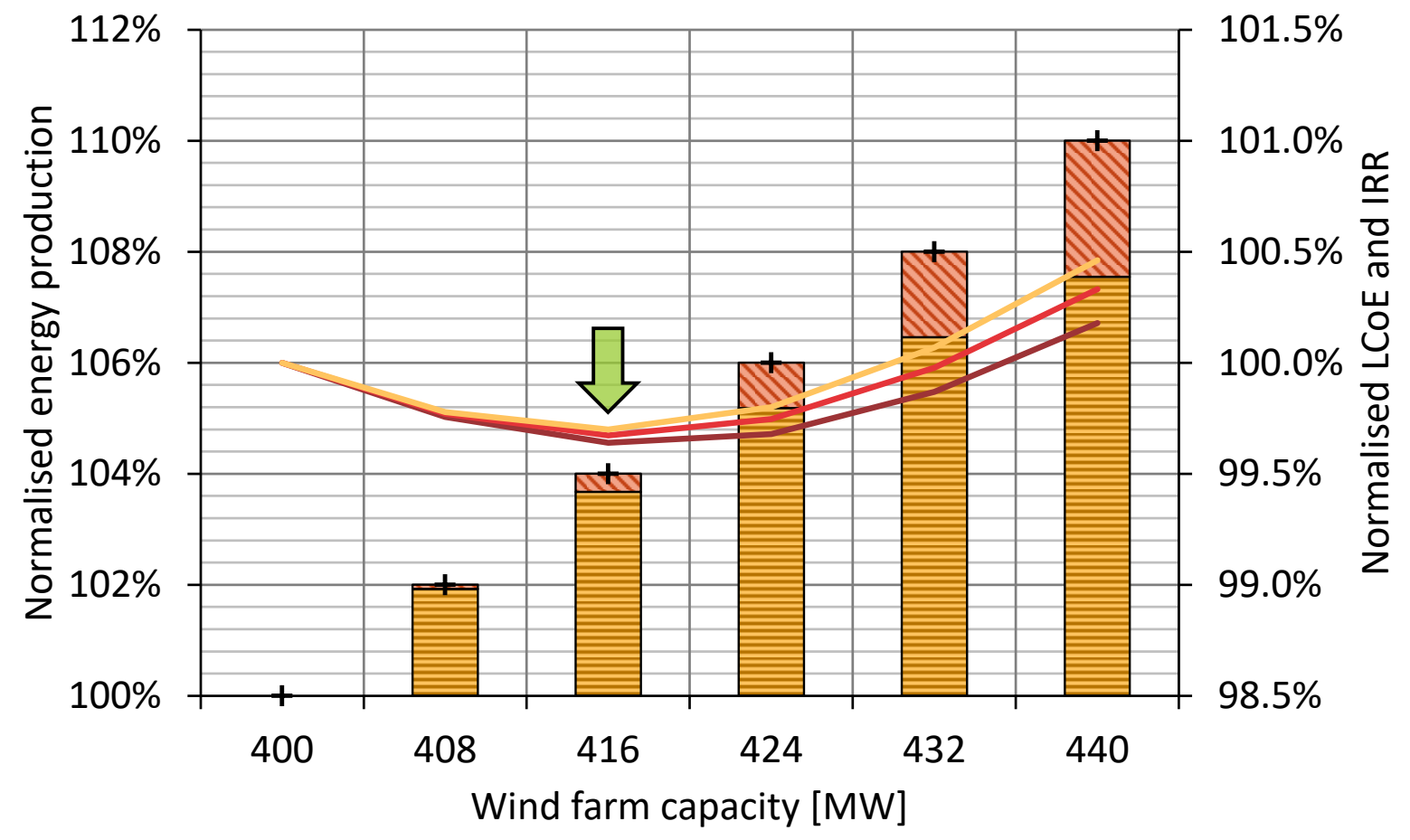

$-\mathrm{LCOE}-9 \mathrm{~m} / \mathrm{s} \quad-\mathrm{LCOE}-9.5 \mathrm{~m} / \mathrm{s} \quad-\mathrm{LCOE}-10 \mathrm{~m} / \mathrm{s}$

Figure 7: Sensitivity of wind potential 
Since the magnitude of $\mathrm{LCoE}$ is comparable over the different sensitivities, it is worth considering to use overplanting as a measure to hedge against risk of unforeseen turbine outages. Lower availability can also stem from unexpectedly low energy generation of the power plant or missing returns that were budgeted in the project. It is also apparent from the figure that with lower mean turbine availabilities the cost reduction trend becomes more flat around the optimal level. This allows for choosing to install a slightly higher additional generation capacity than the analysis suggests, thereby accounting for uncertainties in the estimation of AEP. Risk averse investors could therefore consider to use overplanting as a means to secure the project against any unforeseen lower operational performance than budgetted, be it either due to errors in the initial planning or lower availability in the long run due to ageing of turbines and degradation of blades or other components. As offshore wind farms are becoming more and more attractive for risk averse investors like pension funds that usually have a long-term investment strategy, overplanting can be of further benefit targetting this investor group.

In the same way, additional overplanting beyond the optimal point could counteract other factors like wind farm blockage effects in relation to wake losses, where there is some uncertainty in the industry whether this historically has been underestimated in simulation models, or the effect of external wake losses induced by other wind power plants in the same or adjacent clusters, which is a phenomenon likely rising in the future along with the increased deployment of offshore wind. 


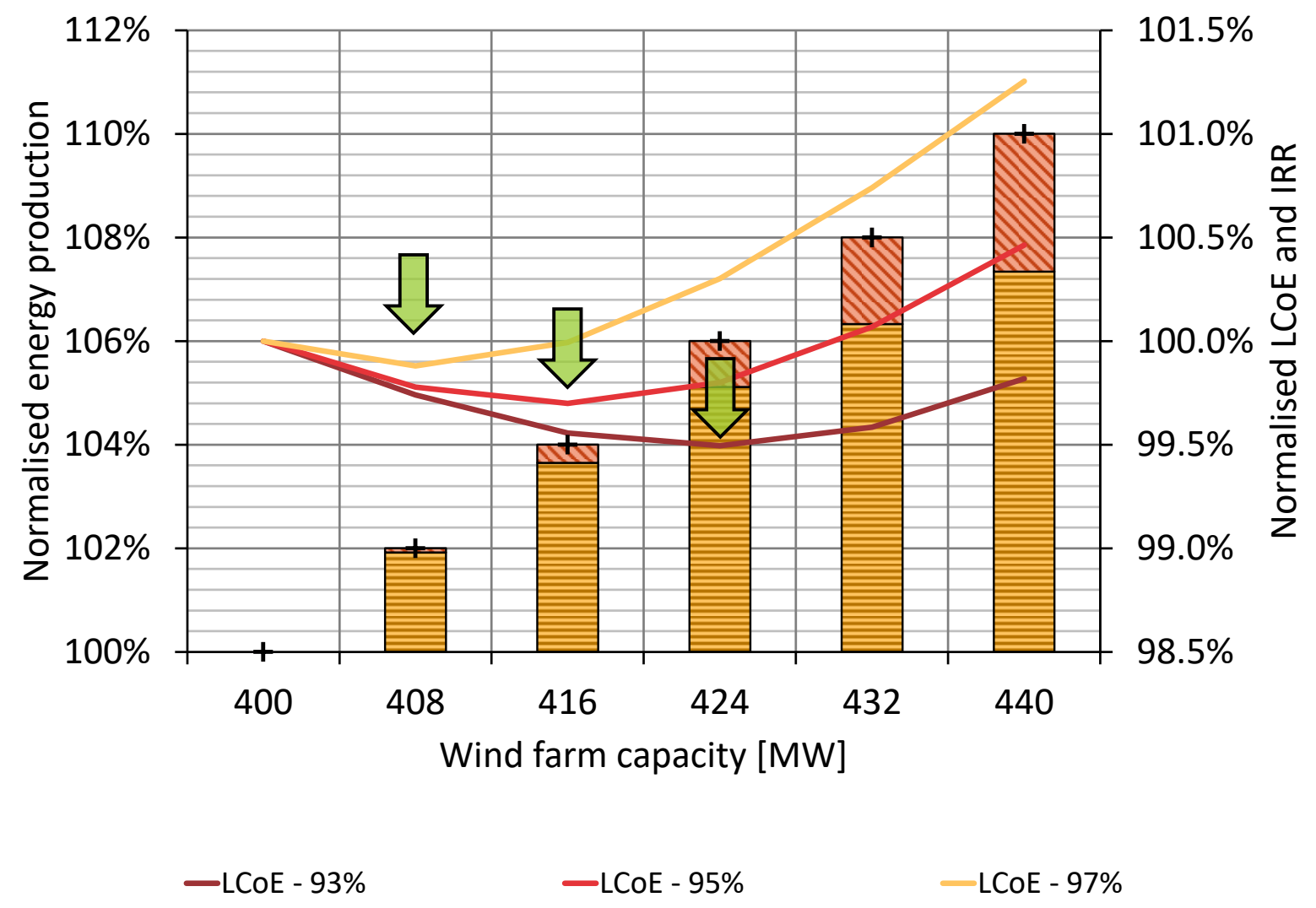

Figure 8: Sensitivity of turbine availability 


\section{Discussion and conclusion}

The aim of this paper was to quantify the impact of regulatory regimes and geographical characteristics on the viability of the capacity optimisation measure of overplanting. The regulatory regimes of the United Kingdom, the biggest offshore wind market, and Denmark, the first country deploying offshore wind, were contrasted. The aptness of their respective regulatory regimes towards overplanting were examined based on different scenarios. Three offshore wind power plants were established that represent a broad range of possible prospective offshore wind projects in both countries. The key differences in the regulatory regimes decisive for the economic viability of overplanting are the remuneration of support payments, the allocation of development responsibilities of the total offshore wind investment project as well as the general prospects of remuneration levels on the national power markets.

It was found that a basic cost reduction potential per generated energy and thereby optimisation of the utilisation of transmission capacity can be achieved in both countries despite different cost allocation regulations. The increase in AEP and linked rise of capacity factors as well as static project planning costs, which overall are not affected by rising levels of installed capacity, contribute to an observable benefit in LCoE when applying overplanting. Static transmission system costs play a more significant role first for considerably long distances to shore, which are not present within the contemporary planned offshore wind projects in Denmark, while more and more projects in the United Kingdom are being developed far from shore.

The socioeconomic benefits of overplanting are identifiable regardless of the inclusion of TSOs in grid infrasturcture cost, but smaller when grid infrastructure attribution is outside the wind farm developer's own planning scope. Other analyses in contrast have found different reasons for keeping a split responsibility for generation and transmission capacity between the wind farm and grid developer in order to maximise socioeconomic benefits, mainly due to the argument that the different developers have different expertise and thus can lift the respective investments with lower cost of capital each (Weissensteiner, Haas, \& Auer, 2011). This argument has however been of higher importance in the high subsidy and high cost of capital environments of some years ago, whereas the offshore wind sector nowa- 
days is characterized by low subsidies and low cost of capital, as well as general consolidation and a maturization of both technology and market participants. The British sector has been a prime example for an integrated approach, which the Danish regulation has embraced in 2019 .

However, the crucial drawback for overplanting of the Danish regulations was determined to be the energy-based remuneration of support prices. Fixing support payments to a certain amount of generated energy counteracts the installation of additional capacity, since firstly, the increased energy output reduces the time span, in which the overplanted offshore wind power plant is remunerated by the tendered support price; and secondly, since the additionally installed turbines and capacity are not generating respectively more subsidies, but instead cannibalize the residual turbines' subsidised generation. Thus the plant receives less subsidies per each turbine in the setup of overplanting, which is not counterbalanced by the temporal aspect of receiving a greater amount of the higher support price payments earlier. The LCoE reduction potential would therefore not be exploited by an investor, since rather the return on investment is decisive for the project evaluation. In order to make it worth installing a higher generation capacity, the additional energy generation of this capacity would need to be remunerated equally as the generation of the baseline capacity over the lifetime of the offshore wind power plant. This is guaranteed by a time-based remuneration of support prices that fixes the subsidy payment period to a certain number of years, as is it present in the United Kingdom, rather than a specific amount of energy or full-load hours, respectively. We find that the demonstrated cost reduction potential of overplanting can justify a reconsideration of the reference of support payments in the Danish regulations. Even though some Danish regulations were amended in 2019 with the private investor in the future being financillay responsible for the transmission system infrastructure as well, this adaption is not enough to make overplanting private-economically attractive when at the same time keeping a fixed energy level as basis for subsidies. In zero-subsidy environments however, this effect of the regulatory framework would vanish, expectedly making overplanting a viable option in private-economic evaluations as well.

The analyses of this paper were backed by other literature examining optimal overplanting levels. The majority of works examining overplanting result in a one-digit percentage increase 
of generation capacity, which is comparable to the different cases explored herein. Some of the literature's analyses have been investigating overplanting either considering it isolated from other optimization measures or integrated with other technical or economical considerations like dynamic cable rating, showing that overplanting can be combined with other measures into a more integrated optimization approach (Hernandez-Colin \& Pilgrim, 2019; Pérez-Rúa et al., 2019). Others have put more focus on economic characteristics as investors' risk aversion, which is allowing more room for overplanting in order to hedge against project risk (Borràs Mora et al., 2019), not necessarily striving for the case-specific optimal level, but rather as an implicit bonus against the benchmark of no overplanting at all. The National Grid's optimal level of $12 \%$ of overplanted capacity for far offshore plants seems like an outlier in the set of literature, but can be explained by the study's conservative assumptions, of which especially the low turbine availability of $90 \%$ raises the optimal level considerably. Equally, the study found turbine availability to be a more dominant driver compared to varying wind climate. The various results show that optimal overplanting levels are highly case-secific and should be investigated separately for each new project, rather than deriving the optimal level from separate references.

The present work focused on a capacity optimisation independent of other impacts of planning considerations of offshore wind power plants. Besides, overplanting can further be embedded into other areas of optimisation for offshore wind power plants. Additionally, it could be used together in hybrid plants like floating PV or wave power where applicable and provided that those technologies will develop or break the stalled development in the future, respectively. The different generation profiles of the supplementary generation technologies would expectedly lead to higher overinstallation with respect to the overall capacity of the hybrid plant by making use of the transmission system infrastructure jointly. On the other hand, constraints or pareto-optima might be found when linking the capacity optimisation with the park layout optimisation, and with that the related array cable routing as well as the optimisation of estimated AEP considering wake effects between the turbines. These impacts however are considered to be small due to the comparatively little change in costs and AEP, respectively, that these aspects can induce. Further benefits expected to show greater positive effects can be achieved when considering overplanting together with dynamic cable 
rating and temporal loadings of the export cable over the nominal transmission level, thereby reducing the amount of curtailment and further increasing the additional energy generation. Overplanting thus is expected to be able to show greater benefits than presented in this paper. 


\section{Acknowledgements}

This paper is based on work carried out in a MSc thesis project at the Technical University of Denmark in cooperation with Ørsted, and related to the Wind2050 project. Outcomes of the work were also presented at the $15^{\text {th }}$ Wind Integration Workshop and published in the workshop's proceedings.

\section{References}

4C Offshore. (2016). 4C Offshore. http://www.4coffshore.com/.

Baldock, N., \& Henderson, A. (2014). Money Does Grow on Turbines. Overplanting Offshore Windfarms. Global Offshore Wind Conference.

Borràs Mora, E., Spelling, J., \& van der Weijde, A. (2019). How does risk aversion shape overplanting in the design of offshore wind farms? Journal of Physics: Conference Series, 1356(1). Retrieved from https://iopscience.iop.org/article/10.1088/ $1742-6596 / 1356 / 1 / 012026 /$ meta

Chen, P., \& Thiringer, T. (2017). Analysis of Energy Curtailment and Capacity Overinstallation to Maximize Wind Turbine Profit Considering Electricity Price - Wind Correlation. IEEE Transactions on Sustainable Energy, 8(4), 1406-1414.

Commission of Energy Regulation (CER). (2014). Decision on Installed Capacity Cap. Decision Paper COPP Installed Capacity Cap.pdf.

Danish Energy Agency. (2015). Levelized cost of energy - LCoE calculator: Methodology, assumptions and guidelines. https://ens.dk/en/our-responsibilities/ global-cooperation/levelized-cost-energy-calculator.

Danish Energy Agency. (2016a). Forudsatninger for samfundsøkonomiske analyser på energiområdet (Guide in socioeconomic analysis from the Danish Energy Agency). https://ens.dk/sites/ens.dk/files/Analyser/samfundsoekonomiske _beregningsforudsaetninger_2016_v3.pdf.

Danish Energy Agency. (2016b). Technology Data for Energy Plants (Updated chapters). https://ens.dk/en/our-services/projections-and-models/technology-data. 
Danish Energy Agency. (2017). Danish Experiences from Offshore Wind Development. https://ens.dk/sites/ens.dk/files/Globalcooperation/offshore_wind _development_0.pdf.

De Jonghe, C., van Hertem, D., \& Belmans, R. (2009). Cost-Efficient RES-E Deployment: Under-Investment in Offshore Wind Transmission Capacity. Working Paper, KU Leuven. Retrieved from https://lirias.kuleuven.be/1730757?limo=0

DECC (Department of Energy \& Climate Change). (2013). Electricity Generation Costs (No. July). doi: 267393///1/125May2010

DECC (Department of Energy \& Climate Change). (2016a). Contracts for Difference (CFD) Allocation Round One Outcome.

DECC (Department of Energy \& Climate Change). (2016b). UK Energy Statistics (No. March).

Dicorato, M., Forte, G., Pisani, M., \& Trovato, M. (2011). Guidelines for assessment of investment cost for offshore wind generation. Renewable Energy, 36(8), 2043-2051. Retrieved from http://dx.doi.org/10.1016/j.renene.2011.01.003 doi: 10.1016/ j.renene.2011.01.003

DTI (Department of Trade and Industry). (2007). Study of the costs of offshore wind generation. http://webarchive.nationalarchives.gov.uk/+/http:/www. berr.gov.uk/ files/file38125.pdf.

Energinet.dk. (2016). Download of market data. Retrieved from http://www. energinet.dk/ EN/El/Engrosmarked/Udtraek-af-markedsdata/Sider/default . aspx

EWEA. (2015). Balancing responsibility and costs of wind power plants. http:// WWw . ewea.org/fileadmin/files/library/publications/position-papers/ EWEA-position-paper-balancing-responsibility-and-costs.pdf.

EWEA. (2016). The European offshore wind industry - key trends and statistics 2015 (No. February). http://www.ewea.org/fileadmin/files/library/publications/ statistics/EWEA-European-Offshore-Statistics-2015.pdf.

Fichtner, \& Prognos. (2013). Cost Reduction Potentials of Offshore Wind Power in Germany. https://www . offshore-stiftung.de/sites/offshorelink.de/files/pictures/ SOW_Download-EN_ShortVersion_CostReductionPotentialsofOffshoreWindPower 
.pdf.

GWEC. (2014). Offshore Wind Policy and Market Assessment - A global outlook. http://www.gwec.net/wp-content/uploads/2015/02/FOWIND_offshore_wind _policy_and_market_assessment_15-02-02_LowRes.pdf.

Heptonstall, P., Gross, R., Greenacre, P., \& Cockerill, T. (2012). The cost of offshore wind: Understanding the past and projecting the future. Energy Policy, 41, 815-821. Retrieved from http://dx.doi.org/10.1016/j.enpol.2011.11.050 doi: 10.1016/ j.enpol.2011.11.050

Hernandez-Colin, M., \& Pilgrim, J. (2019). Cable Thermal Risk Estimation for Overplanted Wind Farms. IEEE Transactions on Power Delivery, 1356. doi: 10.1109/TPWRD .2019 .2917789

Hirth, L. (2013). The market value of variable renewables - The effect of solar wind power variability on their relative price. Energy Economics, 38, 218-236.

IRENA. (2012). Renewable Energy Technologies: Cost Analysis Series Wind Power (Vol. 1) (No. 5). https://www.irena.org/DocumentDownloads/Publications/RE _Technologies_Cost_Analysis-WIND_POWER.pdf.

Kitzing, L., \& Morthorst, P.-E. (2015). Trends in offshore wind economics the past and the future. Proceedings - 14th Wind Integration Workshop. http://orbit.dtu.dk/ files/117692803/Trends_in_off_shore_wind_economics.pdf.

Klinge Jacobsen, H., \& Schröder, S. T. (2012). Curtailment of renewable generation: Economic optimality and incentives. Energy Policy, 49.

KPMG. (2014). Offshore Transmission: An Investor Perspective Update Report. https://www .ofgem.gov.uk/ofgem-publications/85943/offshoretransmission -aninvestorperspective-updatereport.pdf.

McInerney, C., \& Bunn, D. W. (2017). Optimal over installation of wind generation facilities. Energy Economics, 61, 87-96. doi: 10.1016/j.eneco.2016.10.022

National Grid. (2008). Round 3 Offshore wind farm connection study. Version 1.0. Appendix 1: Offshore Wind Farm installed capacity/connection capacity study. http://www.thecrownestate.co.uk/media/451005/ei-km-in-gt-grid -012009-round-3-offshore-wind-farm-connection-study .pdf. 
Netherlands Enterprise Agency. (2016). General information Borssele WFZ. http:// offshorewind.rvo.nl/generalborssele.

Pérez-Rúa, J., Das, K., \& Cutululis, N. (2019). Cable Thermal Risk Estimation for Overplanted Wind Farms. International Journal of Electrical Power \& Energy Systems, 113, 982-990. Retrieved from https://doi.org/10.1016/j.ijepes.2019.06.026

Prässler, T., \& Schaechtele, J. (2012). Comparison of the financial attractiveness among prospective offshore wind parks in selected European countries. Energy Policy, 45, 86-101. Retrieved from http://linkinghub.elsevier.com/retrieve/pii/ S0301421512000894 doi: 10.1016/j.enpol.2012.01.062

PwC. (2012). Offshore wind cost reduction pathways study - Finance work stream. http://www.thecrownestate.co.uk/media/451398/ei-km-in-pe-cost -052012-off shore-wind-cost-reduction-pathways-finance-workstream.pdf.

TKI Wind op Zee. (2016). Top consortium for Knowledge and Innovation Offshore Wind. http://www.tki-windopzee.eu/.

TKI Wind op Zee. (2019). The Netherlands'Long-Term Offshore Wind RED Agenda. Retrieved from https://www.topsectorenergie.nl/sites/default/files/ uploads/Wind\%20op\%20Zee/Documenten/20190930_RAP_The-Netherlands-long -term-offshore-wind-R-D-Agenda_V05-w_0.pdf

Van der Zwaan, B., Rivera-Tinoco, R., Lensink, S., \& van den Oosterkamp, P. (2012). Cost reductions for offshore wind power: Exploring the balance between scaling, learning and R\&D. Renewable Energy, 41, 389-393. Retrieved from http://dx.doi.org/ 10.1016/j.renene.2011.11.014 doi: 10.1016/j.renene.2011.11.014

Van Eeckhout, B., Van Hertem, D., Reza, M., Srivastava, K., \& Belmans, R. (2009, jun). Economic comparison of VSC HVDC and HVAC as transmission system for a 300 MW offshore wind farm. European Transactions on Electrical Power. Retrieved from http://doi.wiley.com/10.1002/etep.359 doi: 10.1002/etep.359

Voormolen, J. A., Junginger, H. M., \& van Sark, W. G. J. H. M. (2015). Unravelling historical cost developments of offshore wind energy in Europe. Energy Policy, 88, 435-444. Retrieved from http://dx.doi.org/10.1016/j.enpol.2015.10.047 doi: 10.1016/j.enpol.2015.10.047 
Weissensteiner, L., Haas, R., \& Auer, H. (2011). Offshore Wind Power Grid Connection The impact of shallow versus super-shallow charging on the cost-effectiveness of public support. Energy Policy, 39, 4631-4643. doi: https://doi.org/10.1016/j.enpol.2011.05 .006

Wind Europe. (2019). Offshore Wind in Europe - Key trends and statis-

tics 2018. https://windeurope.org/about-wind/statistics/offshore/european -offshore-wind-industry-key-trends-statistics-2018/. 